\title{
Roots of the Mongolian State: Genghis Khan's Survival and Pragmatism as related in the Secret History of the Mongols
}

\author{
By Robert Bedeski
}

Professor Emeritus, University of Victoria, Canada Affiliate Professor, University of Washington The Ellison Center for Russian, East European and Central Asian Studies

\begin{abstract}
:
The genesis of the first Mongol State (1206) was overseen and led by Genghis Khan, whose conquests remain a formidable historical series of events. The Secret History of the Mongols narrates his biography as a tale of surviving repeated life threats and defeating major enemies. From this history, I have extracted an existential framework to explain how he survived in a dangerous natural, social and political environment. The rise of this State compressed what occurred in most other historical States, and I will summarize my Anthrocentric Security Theory as general explanation of this phenomenon, drawing on Western philosophy, especially philosophical anthropology. The framework consists of four levels of Being - state of nature, life- community, State, and civil society. Each level has enabled humans to devise several Security Action Platforms from which are launched particular security actions, culminating in the State. Successful in three stages, but not in creating a civil society, the Mongol State assimilated and absorbed the strengths of natural men and lifecommunities, enabling the expansion into Eurasian empire under his sons and grandsons.

(Author's note: This paper is a summation of my book-length manuscript, available at Sustaining Existence: Lessons from Genghis Khan, A Theory of Life Security, and Roots of the Asiatic State. https://digital.lib.washington.edu/ researchworks/handle/1773/38457)
\end{abstract}

This article is published under the Creative Commons CC-BY-ND License (http://creativecommons.org/licenses/by-nd/4.0/). This license permits use, distribution and reproduction, commercial and non-commercial, provided that the original work is properly cited and is not changed anyway. 
Dedication: To Dr. Ts. Batbayar, whose love of country, tireless scholarship, and outstanding organizational accomplishments have significantly contributed to international understanding and appreciation of modern Mongolia.

\section{A Philosophical Anthropology approach}

Genghis Khan has the reputation as a man of death and destruction, and yet he set in motion a chain of events which transformed much of Eurasia. He ushered in a renovation which ranks with modern globalization today. His career triggered a historical Big Bang whose force and effects are still rippling through the present day. The moment of that explosion began on the steppes of Mongolia, where one man forged warring clans and tribes into one of the greatest fighting forces in history.

My interest in Mongolia began in the early 1990s. Thanks to an invitation by Dr. Ts. Batbayar, I was able to meet with top political leaders and discuss democratic development and problems of national security. My previous work on democracy in Northeast Asia, State formation, and national security stimulated further curiosity about how this former Soviet satellite would solve some fundamental political questions. In the course of several visits, and a Swedish invitation to write and lecture on contemporary Mongolian affairs, my attention turned to the medieval State. In reading about Genghis Khan and studying the Secret History of the Mongols, I discovered the convergence of several clusters of ideas waiting to be explored. The first was about State formation - how did the Mongol State emerge out of violent tribal wars and politics? Was there a Hobbesian social contract where men consciously agreed not to fight each other and to create a sovereign to rule over them? The second cluster concerned the concept of security - a word with promiscuous modern usage. By confining it to precisely one meaning, a pattern of survival became clear in the Secret History. From this second cluster, a third emerged the perennial question of human existence - how is it possible to stay alive in a hostile world and cosmos? And yet humanity has prevailed. Answering the question of how our species has survived must begin at an individual level.

To provide a framework for approaching these questions, I expanded some ideas from philosophical anthropology. I identify four levels of existence, or Strata-of-Being, starting from autonomous individual human to citizen in civil society. The first three strata are found in the History, and a beginning of the fourth stratum. Furthermore, one finds that each stratum is energized 
by a different version of human Will, and I will illustrate these with incidents from the life of Genghis Khan. More than scholarly exegesis, my approach assumes that history is created by living men exercising inborn Will. This Will is expressed in knowledge and action. Mongols lived at the edge of physical survival and understood this, following Genghis Khan and recognizing that his enterprise of war and conquest was more conducive to their life security than was traditional tribal and nomadic existence.

A primary lesson we can derive from the Secret History is that security of human life is enhanced by Will, knowledge and action, and that the primary motivation and orientation of all living things is to remain alive. Material conditions are important but secondary.

Man has refined and improved his life chances more than any other biological species. He has modified his behavior, constructed social and political institutions, and transformed nature from adversary into life sustainer.

\section{Growth in human life security, 10,000 BC to $2000 \mathrm{AD}$}

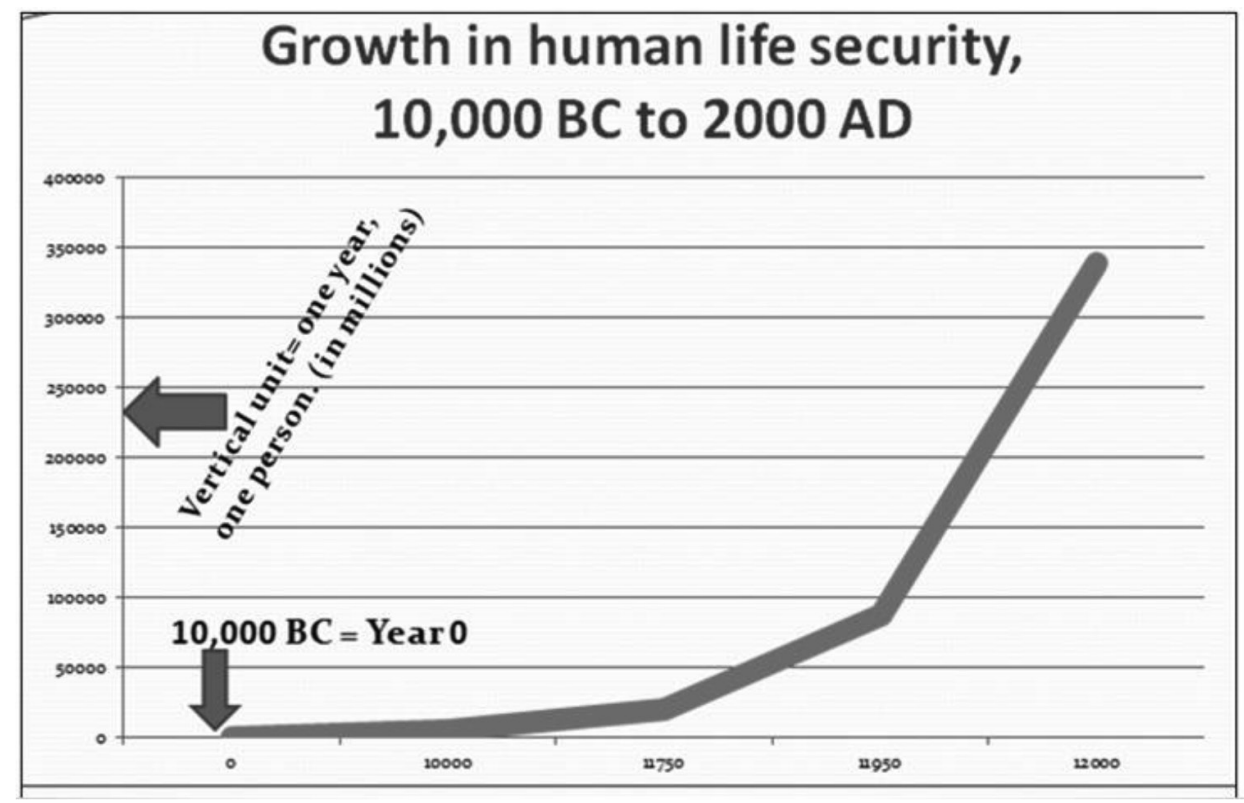

Figure 1: Historical growth of life security

Historical growth of life security

A humanist understanding of Genghis Khan requires an approach which is faithful to historical description, considers psychological parsing, and transcends materialist explanation. Two thematic questions dominate the 
Secret History: "How was he able to survive in the frequently life-threatening environment of the nomadic steppe?" And "How did the Mongol State emerge out of the unpromising conditions of tribal and impoverished warrior society? ${ }^{11}$ Both questions were approached pragmatically and empirically in the Secret History. Empiricism as "knowing"and pragmatism as "acting" form the " $\mathrm{x}$ " and "y" axes of the History. By plotting knowledge and action in response to lifeending threats, we gain an appreciation of Genghis Khan's survival dilemma, and by extension, man's in general.

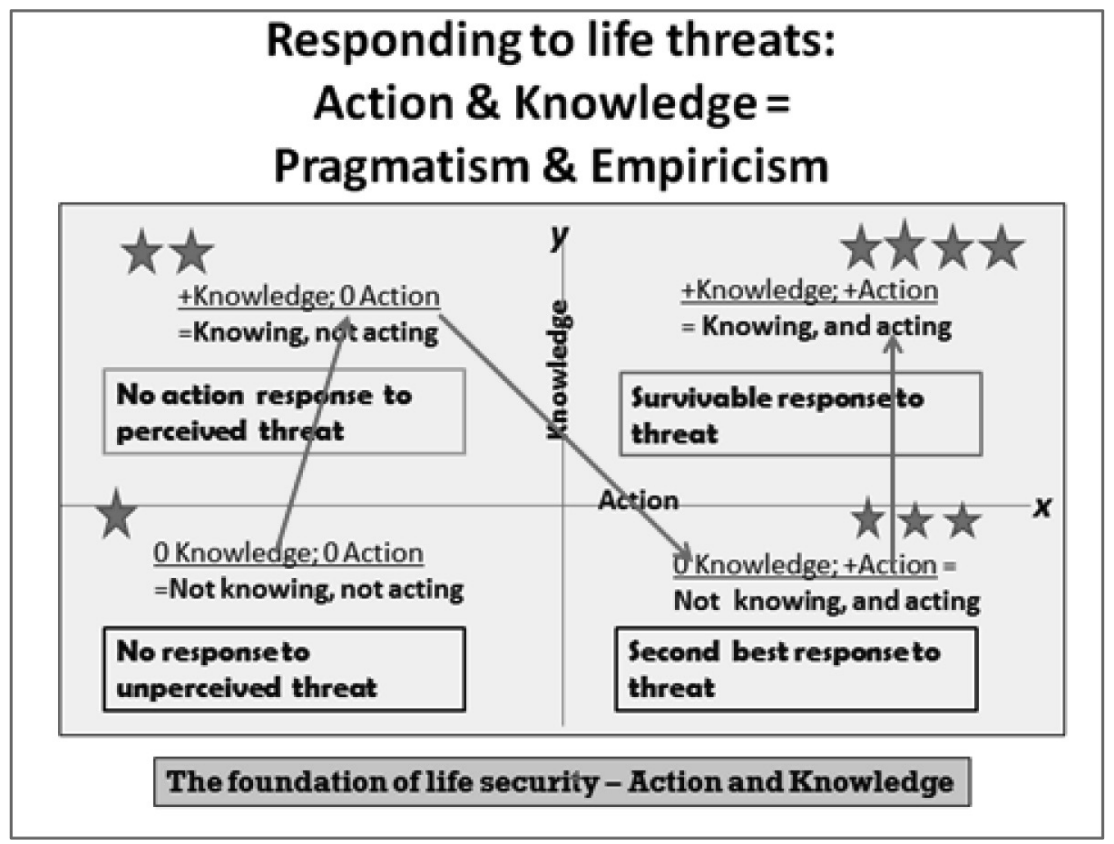

Figure 2: Action and knowledge - importance in life security

We can illustrate how knowledge and action affect life security or mortal existence by considering four scenarios of a hunter in a cave when a fierce tiger enters. In Scenario One, he is sleeping and completely vulnerable, having no awareness of the tiger, and taking no protective action. In the next scenario, he is aware of the tiger, but is paralyzed by fear into inaction. Scenario three, in darkness, he is aware of an unknown predator, and flails at it with bare hands or whatever weapon available. In the last scenario, he sees the tiger, knows its weak points, has weapons, and fights skilfully. His probable survival is greatest when action is informed by knowledge. Empiricism and pragmatism, as knowledge and action, permeate the Secret History, narrating a central message of State formation around the survival of Tembjin, and his acquisition of power 
to protect himself, his family, and his warriors with their families and clans.

Explaining his longevity can be distilled to the relative presence of security - a term we generally apply to States and nations, but one which traditionally referred to individuals. Since "life" is the fundamental property of an individual, and life is not possible without constant inputs of fluids, nutrition, shelter and protection from predators, security can be defined as the sum of actions which sustain life. Individual human units comprise the molecules of society and State, consume security actions in order to prolong life, and postpone death. Thus life security can be defined as prolonging life, postponing death, or PLPD. Life security can be precisely measured as the longevity of an individual as the consumer and producer of security actions. For every person who has lived, is living, and will live, life-length is roughly proportional the degree of security absent or present.

Below, I illustrate this thesis with events in the life of Genghis Khan. All humans are born, live and die attached to a state of nature in that longevity of mortal bodies is subordinate to metabolism and physiology. The mortal soul resides in the physical body, and is dependent on its survival and health.

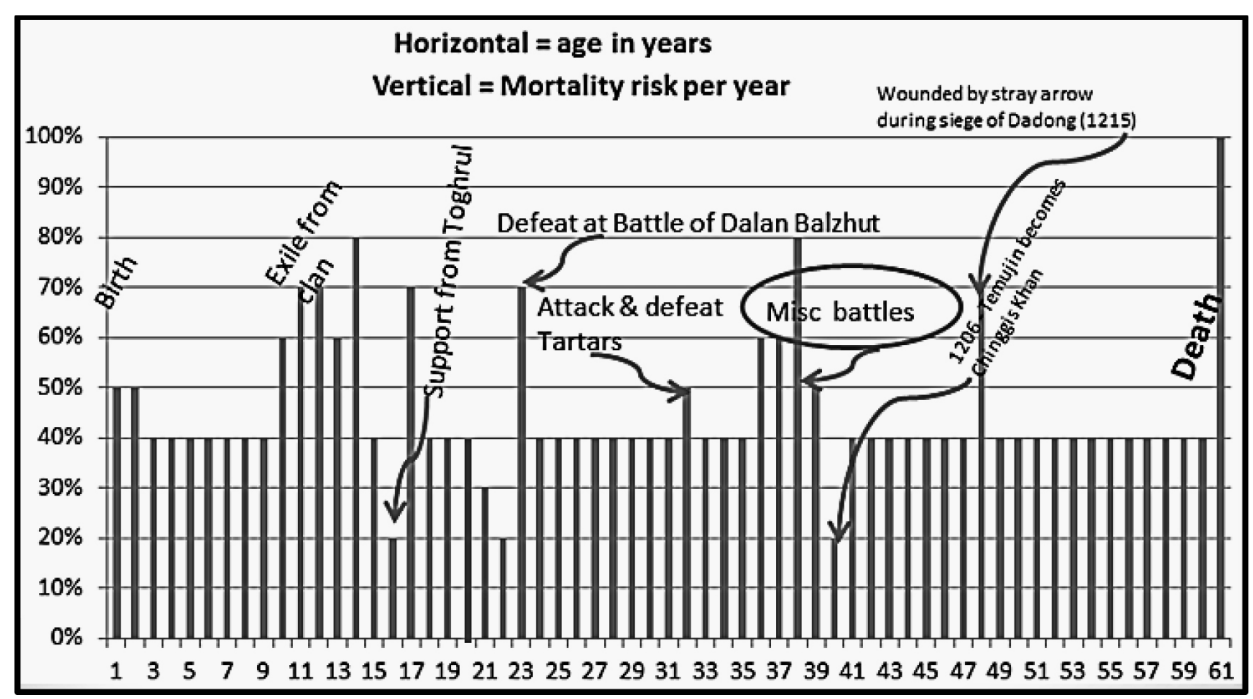

Figure 3: The Perilous Life of Genghis Khan

(This graph is for illustration purposes only, and represents the author's judgment on the highest threat to Genghis Khan's life security in each year, based on events noted in the Secret History of the Mongols)

In the course of evolution humans constructed nuclear families which formed the basis of clans and tribes - or life-communities as families writ large. 
From these, men constructed States primarily for the purpose of enhancing life security. A concentration of power and control was summarized in the concept of sovereignty - a supremacy mimicking the paterfamilias in the family and a supreme being in religion.

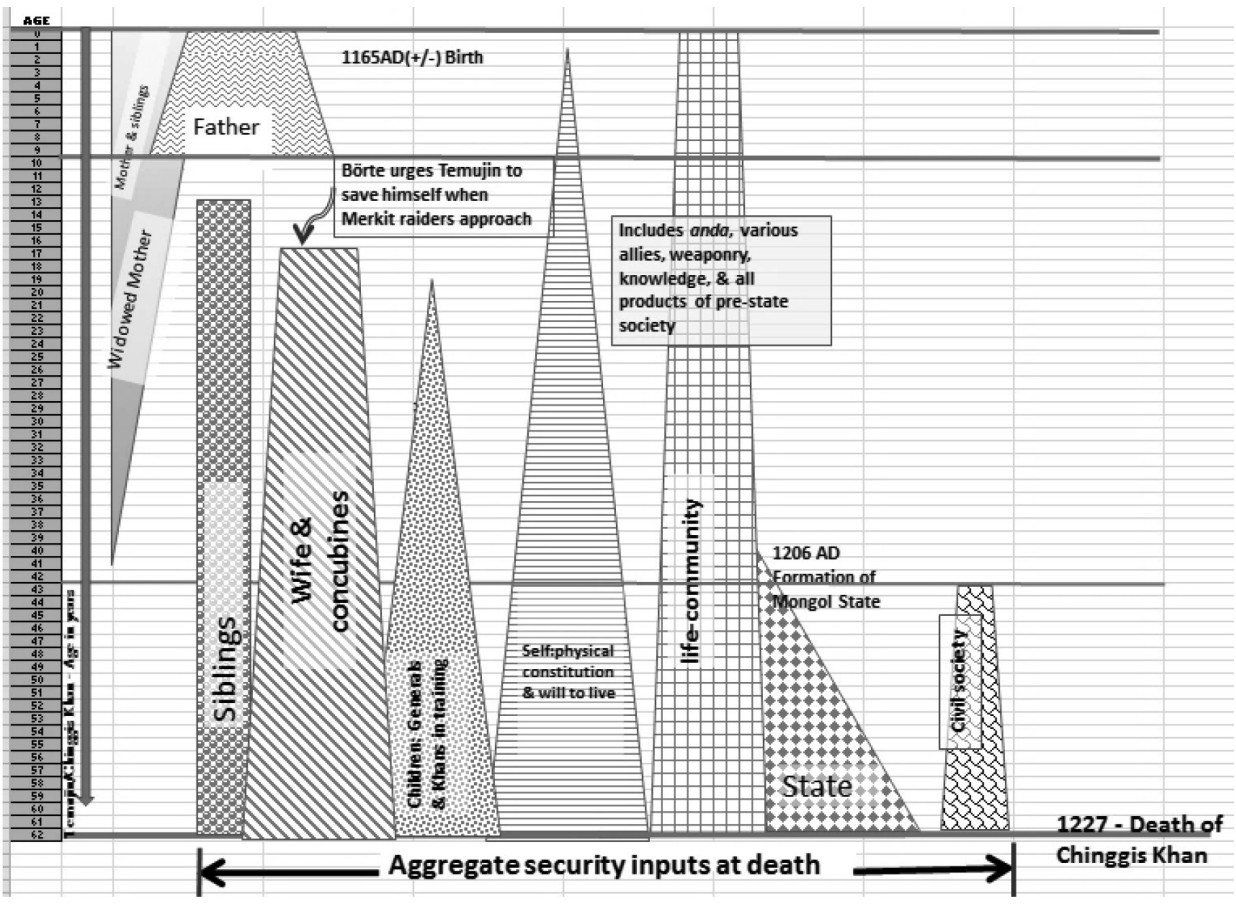

Figure 4: Security inputs to the life of Genghis Khan

Thomas Hobbes described the sovereign as keeper and guardian of the social contract wherein men partially surrendered their right of self-defense in exchange for collective protection by the State. A powerful metaphor, but he minimized the intermediate step which created pre-State life-community - a vital stage for evolution of all States and the Mongol empire in particular. $\mathrm{He}$ was writing from experience in Britain and Western Europe, where State and civil society enjoyed a relatively high degree of partnership and had evolved from the time of the Roman conquest. The Mongol State, in contrast, was based on a sovereignty imposed by force and violence, yet supported by component life-communities.

The later empire's bi-continental extent, as well as multi-faith and multiethnic population, precluded an integrated civil society, and required a powerful State apparatus to maintain order. An unsustainable single sovereignty was 
replaced by multible khanates ruling through Chinggisid claims, and ending in fragmentation. The Secret History of the Mongols describes events of life security and sovereignty formation to illustrate a theory of Anthrocentric Security - anthrocentric because all security actions originate with living men and women. The theory's postulates are the following:

1. All human life consists of individual birth, a life of creating and consuming security actions, and an end.

2. All humans have a mortal soul which consists of:

- Will-to-Life - Schopenhauer's idea of life-force;

- Will-to-Freedom - the reduction of material necessity as the primary motive of action; and

- Will-to-Power - Nietzsche's Ubermensch spark which resides in a human elite.

3. Each Will constructs a Stratum-of-Being as follows and establishes human status:

- Will-to-Life State of nature Individual

- Will-to-Freedom^^ Life-community^ ${ }^{\wedge}$ Person

- Will-to-Power ${ }^{\wedge}$ State $^{\wedge}$ Ruler and Subjects

4. Each Stratum-of-Being discovers or creates platforms from which security actions are launched. These actions may be positive or negative, depending on their effect on lives of self and others. These Security Action Platforms are summarized in the following table.

5. Every life-year of an individual could be the last, and completion of each year after birth suggests that a quantity of security resources were consumed. (In life-community and State, the person/Subject is required to contribute security resources. Reciprocity may be weaker in the state of nature.)

6. That which is consumed must first be produced.

Sustaining the life-community and State Strata-of-Being as life protections requires production of positive security resources for members and of negative ones against predators and enemies. The greater the membership and average age of members of a population, the greater the probability that security resources have been effectively deployed. Wealth can be a reasonable proxy for security since material adequacy and surplus is an important buffer against adversity.

The theory of anthrocentrie security is summarized in Figure 5. 
Roots of the Mongolian State: Genghis Khan's Survival and Pragmatism as related in the Secret History of the Mongols

Stratum-of-Being (SB,.3)

\begin{tabular}{|c|c|}
\hline Stratum-of-Being (SB $1-3)$ & Security Action Platform (SAP $\left.{ }_{1-15}\right)$ \\
\hline & 1. Will-to-Life $\left[\mathrm{W}_{\mathrm{N}}\right]$ \\
\hline \multirow[t]{5}{*}{ State of nature (SB1) } & 2. Family $\left[F_{N}\right]$ \\
\hline & 3. Practical knowledge $\left[\mathrm{K}_{\mathrm{N}}\right]$ \\
\hline & 4. Natural environment $\left[E_{\mathrm{N}}\right]$ \\
\hline & 5. Will-to-Freedom $\left[\mathrm{W}_{\mathrm{L}}\right]$ \\
\hline & 6. Cultural knowledge $\left[\mathrm{K}_{\mathrm{L}}\right]$ \\
\hline \multirow[t]{5}{*}{ Life-community $\left(\mathrm{SB}_{2}\right)$} & 7. Social Obligation $\left[\mathrm{O}_{\mathrm{L}}\right]$ \\
\hline & 8. Social economy $\left[E_{L}\right]$ \\
\hline & 9. Social concord $\left[\mathrm{C}_{\mathrm{L}}\right]$ \\
\hline & 10. Political obligation $\left[\mathrm{O}_{S}\right]$ \\
\hline & 11. State economy $\left[\mathrm{E}_{S}\right]$ \\
\hline \multirow[t]{4}{*}{ State $\left(\mathrm{SB}_{3}\right)$} & 12. Political knowledge $\left[\mathrm{K}_{\mathrm{S}}\right]$ \\
\hline & 13. Coercive institutions $\left[I_{S}\right]$ \\
\hline & 14. Political concord $\left[\mathrm{C}_{S}\right]$ \\
\hline & 15. External relations $\left[\mathbf{R}_{S}\right]$ \\
\hline
\end{tabular}

Figure 5: Summary of Anthrocentric Security Theory

A more precise rendering of life security actions (to be illustrated in Secret History incidents) is summarized in three equations:

\section{Formulizing Life Security}

\begin{tabular}{l} 
Equation One: Life Security of an individual in the \\
state of nature Stratum-of-Being: \\
\hline $\mathbf{L} \mathbf{S}_{\mathbf{N}}=\mathrm{W}_{\mathrm{N}}+\mathrm{F}_{\mathrm{N}}+\mathrm{K}_{\mathrm{N}}+\mathrm{E}_{\mathrm{N}}$ \\
\hline
\end{tabular}

$$
\begin{array}{|l|}
\text { Equation Two: Life Security of a person in the life- } \\
\text { communityStratum-of-Being }\left(\mathrm{SB}_{2}\right): \\
\hline \boldsymbol{L} \boldsymbol{S}_{\boldsymbol{L}}=\mathbf{L S}_{\mathbf{N}}+\mathrm{W}_{\mathrm{L}}+\mathrm{K}_{\mathrm{L}}+\mathrm{O}_{\mathrm{L}}+\mathrm{E}_{\mathrm{L}}+\mathrm{C}_{\mathrm{L}}
\end{array}
$$

$$
\begin{aligned}
& \text { Equation Three: Life Security of a Subject in a State } \\
& \text { Stratum-of-Being: } \\
& L S_{S}=\boldsymbol{L} \boldsymbol{S}_{\boldsymbol{L}}+\mathrm{O}_{\mathrm{S}}+\mathrm{E}_{\mathrm{S}}+\mathrm{K}_{\mathrm{S}}+\mathrm{MS}_{\mathrm{S}}+\mathrm{C}_{\mathrm{S}}+\mathrm{ES}_{\mathrm{S}}
\end{aligned}
$$

Figure 6: Sequence and accumulation of life security actions in formulaic expression. 
1. Equation One: Life Security of an individual in the state of nature Stratum-of-Being:

$$
\mathrm{LSN}_{\mathrm{N}}=\mathrm{WN}_{\mathrm{N}}+\mathrm{FN}_{\mathrm{N}}+\mathrm{KN}_{\mathrm{EN}}
$$

- The life security of an individual existing in $\mathrm{SB}_{1}$ (Stratum-of-Being $=$ state of nature) equals the sum of SAMs launched from SAPs Will-to-Life $\left[\mathrm{W}_{\mathrm{N}}\right]$, family $\left[\mathrm{F}_{\mathrm{N}}\right]$, practical knowledge $\left[\mathrm{K}_{\mathrm{N}}\right]$ and natural environment $\left[\mathrm{E}_{\mathrm{N}}\right]$.

2. Equation Two: Life Security of a person in the life- community Stratumof-Being $\left(\mathrm{SB}_{2}\right)$ :

$$
\mathrm{LS}_{L}=\mathrm{LS}_{\mathrm{n}}+\mathrm{W}_{\mathrm{L}}+\mathrm{K}_{1}+\mathrm{O}_{\mathrm{L}}+\mathrm{E}_{1}+\mathrm{C}_{\mathrm{L}}
$$

- The life security of a person in $\mathrm{SB}_{2}$ (life-community) equals the sum of SAMs launched from SAPs from Equation One plus $\mathrm{SB}_{2}$ SAPs Will-to-Freedom $\left[\mathrm{F}_{\mathrm{L}}\right]$ cultural and social knowledge $\left[\mathrm{K}_{\mathrm{L}}\right]$, social obligation/loyalty $\left[\mathrm{O}_{\mathrm{L}}\right]$, social economy $\left[\mathrm{E}_{\mathrm{L}}\right]$ and social concord variable $\left[\mathrm{C}_{\mathrm{L}}\right]$.

3. Equation Three: Life Security of a Subject in a State Stratum-of-Being:

$$
\mathrm{LSs}=L S l+\mathrm{Os}+\mathrm{Es}+\mathrm{Ks}+\mathrm{Ms}+\mathrm{Cs}+\mathrm{Es}
$$

- The life security of a Subject in $\mathrm{SB}_{3}$ (State) equals the sum of lifecommunity SAMs ${ }^{1}$ launched from SAPs from Equation Two (LS), plus $\mathrm{SB}_{3}$ SAPs political obligation $\left[\mathrm{O}_{\mathrm{S}}\right]$, political economy $\left[\mathrm{E}_{\mathrm{S}}\right]$, political knowledge $\left[\mathrm{K}_{\mathrm{s}}\right]$, protective/coercive institutions[Ms], political concord coefficient $\left[\mathrm{C}_{\mathrm{S}}\right]$, and external relations $\left[\mathrm{E}_{\mathrm{S}}\right]$.

The unit of human protection is the Security Action Monad $^{2}$ (SAM), consisting of a single act or a set of actions launched within a Stratum-ofBeing's Security Action Platform for the purpose of protecting or destroying one or more human lives. Human history consists of trillions and trillions of security monads. Anthrocentric Security Theory does not address civil society in the context of the Secret History because it was not achieved during the lifetime of Genghis Khan among the Mongols. It can be considered a fourth Stratum-of-Being, derived from the three preceding it, and providing a high level of security for a small portion of humanity.

Derived in Equation Two.

"Monad" is a term borrowed from the metaphysics of Leibniz, who considered that the universe consists interacting forces. 


\section{Three illustrative incidents}

To illustrate application of the Anthrocentric Security Theory to Genghis Khan of the Secret History, I offer a framework for analyzing particular Security Action Monads (SAM).

\begin{tabular}{|ll|}
\hline 1. & Stratum-of-Being $=\mathrm{SBi}, \mathrm{SB} 2, \mathrm{SB} 3$ \\
\hline 2. & SAM Platform = SAP1-15 \\
\hline 3. & $\begin{array}{l}\text { Component identification of a SAM: initiator + action }+ \text { target }= \\
\text { subject + predicate }+ \text { object }=\mathrm{S}+\mathrm{P}+\mathrm{O}\end{array}$ \\
\hline 4. & Intended consequence \\
\hline 5. & Unintended consequence(s) \\
\hline 6. & Resources required v. resources used \\
\hline 7. & Effect on life-length of object \\
\hline S. & Positive or negative for subject's (initiator) life security \\
\hline 9, & Positive or negative for object's (target) life security \\
\hline
\end{tabular}

Figure 7:Template for analyzing a Security Action Monad

\section{First illustrative incident: Temuiin kills half-brother Bekter}

Families can be pressure cookers in which rivalry and conflict erupt, sometimes fatally. The family $\left(\mathrm{SAP}_{1}\right)$ can nurture intense emotions, and is capable of hosting negative SAMs between members. Fraternal solidarity was a fragile though vital necessity and not a constant feature. An iconic negative SAM was Temujin's murder of his half-brother, Bekter. The family's expulsion from their tribe both strained and strengthened family solidarity under extreme duress. Game kill theft by Bekter deprived the younger boys offering filial food to Ho'elun.

Bekter was older than Tembjin, and though not a descendant of Yisugei's principal wife, he threatened Temujin's primacy within the family. It is also possible that Tembjin killed Bekter to prevent him from marrying Ho'elun. This incident of fratricide has several elements manifesting the character of Tembjin and has broader implications for human life security. First, it was a microcosm of the wars he would fight in later life. He believed in the justice of his action - a stronger party (Bekter) had stolen what was rightfully his, and 
nobody, not even his mother, would intervene to fix the injustice. Appealing to the stronger party with reason and compromise had no prospect of success and only elimination of Bekter seemed to resolve the conflict. Tembjin became judge, jury and executioner in settling his grievance. Second, his younger brother Qasar had been jointly deprived of their catch, and was the perfect ally. An alliance of two against one accomplished the murder with dispatch. Third, alone in the wilderness, there was no sovereign body to enforce laws or customs, and each man-boy had to look out for himself or be deprived of the essentials of life preservation. Fourth, appeals by Ho'elun to prudence and the practicality of preserving family unity in order to seek vengeance against those who had cruelly deserted them, only stirred the sons to action. Their grievance was immediate, and retribution would be far off. Finally, Bekter, as oldest male in the family, could claim to be the formal head, and Temujin's act removed him as chief rival. The killing is summarized in the Security Action Monad template, Figure 8 .

\begin{tabular}{|c|c|}
\hline 1. Stratum-of-Being & $\begin{array}{l}\text { State of nature (SB-j-as result of } \\
\text { exile. }\end{array}$ \\
\hline 2. Security Action Platform & Familv (SAP-.). \\
\hline $\begin{array}{l}\text { 3. Initiator (subject) + predicate + } \\
\text { target (object) }\end{array}$ & Temujin (with Qasar) + kills + Bekter. \\
\hline 4. Intended consequencef & $\begin{array}{l}\text { To remove Bekter from competition } \\
\text { for food, dominance. }\end{array}$ \\
\hline 5. Unintended consequence & $\begin{array}{l}\text { Demonstrated brittleness of familv } \\
\text { solidarity, and thatthev were not } \\
\text { thatfar from animal existence (See } \\
\text { Ho'eliin's lament). }\end{array}$ \\
\hline 6. Resources required v. used & Bow/arrow; rear attack by Qasar. \\
\hline $\begin{array}{l}\text { 7. Actual effect on life-length of } \\
\text { object }\end{array}$ & Termination. \\
\hline 8. Positive or negative for subject & $\begin{array}{l}\text { +Temiijin removed Bekter as } \\
\text { rival; bound Qasar as allv and co- } \\
\text { executioner } \\
\text {-Aroused new tkreatfrom } \\
\text { Tayid'utwho sought to pumsh } \\
\text { Temujin for his fratricide. }\end{array}$ \\
\hline 9. Positive or negative for Object & Completely negative for Bekter-EOL. \\
\hline
\end{tabular}

Figure 8: Temujin kils Bekter 


\section{Second illustrative incident: Battle with Merkit}

Social obligation tightens human relations and mutual dependency in the life-community. In Mongol nomadic feudalism, vassals and lords entered reciprocal relationships based on interest and loyalty. After Merkit abduction of his wife, Tembjin appealed to liege-lord Toghrul for aid in her rescue. Addressing him as father, he appealed to feudalist reciprocity and obligation, in a family-like political alliance. Toghrul's assistance in wife-retrieval was stated in terms of a tribe-uniting project - not merely restoring the marriage bed. It was also repayment for the valuable coat gift - the symbol (and price) of alliance and obligation. He also implies that uniting the Mongol tribes would be his (Toghrul's) achievement.

In return for the sable coat,

I shall unite for you Your scattered people;

In return for the black sable coat,

I shall bring together for you

Your divided people. ${ }^{3}$

In affirmation of a fictive father-son relationship, the family prototype for inter-tribal bonding was prominent. He mentions or implies the sable coat six times, admitting that his support had been assured with a valuable object. It showed him to be a man of his word in carrying out an obligation, and reliable when it was in his interest. Toghrul ordered Tembjin to invite Jamuqa to join with his thousands. Tembjin returned to his camp and despatched Qasar and Belgbtei to Jamuqa.

When Temujin, Qasar and Belgutei came back from To'oril Qan's camp and arrived at their tent,Tembjin sent both Qasar and Belgbtei to Jamuqa saying, 'Give my sworn friend Jamuqa this message: "When the Three Merkit came, My bed was made empty. You and I, Are we not from one family? How shall we take our revenge? My breast is torn apart. You and I, Are we not of kindred blood? How shall we avenge this injury?"

From these we can extract a cluster of actions (Security Action Monads) launched from $\mathrm{SAP}_{7}$ (Social obligation/loyalty $\left[\mathrm{O}_{\mathrm{L}}\right]$ ) in $\mathrm{SB}_{2}$ (Stratum-ofBeing $_{2}$ ). Arrogant Jamuqa was a superior strategist, and focused on destruction

Rachewiltz 3:104.

4 Rachewiltz 3:105 
of enemies. He estimated the Merkit enemy to have weak leadership. He displayed a warrior instinct and fierce hunger for battle, and saw himself as avenger and destroyer of the Merkit: "We shall utterly destroy his people till nothing will be left.“

\begin{tabular}{|l|l|}
\hline 1. Stratum-of-Being & Life-commurutv “ SB;. \\
\hline 2. Security Action Platform & 07. Social obligation/lovaltv [OI] \\
\hline $\begin{array}{l}\text { 3. Initiator (subject) + predicate } \\
\text { + target (object) }\end{array}$ & $\begin{array}{l}\text { Toghrul + assents to assist + Temujin } \\
\text { (to retake Borte). }\end{array}$ \\
\hline 4. Intended consequence & $\begin{array}{l}\text { 1. Smite the Merkit } \\
\text { 2. Restore Borte to Temiijin. }\end{array}$ \\
\hline 5. Unintended consequence & $\begin{array}{l}\text { Promoted Temujin to major mill tan } \\
\text { actor in Mongol politics. }\end{array}$ \\
\hline $\begin{array}{l}\text { 6. Resources required v. used } \\
\text { Required and used: three armies; careful } \\
\text { strategy Reauired but compromised: } \\
\text { element of surprise due to late arrivals. }\end{array}$ \\
\hline $\begin{array}{l}\text { object } \\
\text { 8. Positive or negative for } \\
\text { subject }\end{array}$ & $\begin{array}{l}\text { Led to restoration of Borte; affirmed a } \\
\text { powerful alliance feeding Will-to-Power } \\
\text { of Temujin. }\end{array}$ \\
\hline $\begin{array}{l}\text { 9. Positive or negative for } \\
\text { object }\end{array}$ & $\begin{array}{l}\text { Toghrul repaid help from Yisiigei; repaid } \\
\text { debt of sable coat; removed threat of } \\
\text { Merkit }\end{array}$ \\
\hline & $\begin{array}{l}\text { All positive for Temujin - confirmed } \\
\text { alliance ivith Ong Qan and Jamuqa. }\end{array}$ \\
\hline
\end{tabular}

Figure 9: Toghrul helps Temujin to rescue Borte from the Merkit

\section{Third illustrative incident: Formation of bodvguard corps}

The principles of Mongol statecraft evolved as empirical knowledge, and pragmatic action accomplished unification. Absent was explicit State legislation and an appeal to rule by law. However, the Secret History offers an example of one precise command, which could have been the model for laws. Genghis gave detailed instructions on the duties and disposition of dayguards, stewards, quiver bearers at night and during the day. Punishment 
was specified for civilians who violated bodyguard lines. The organization and duties were designed to provide maximum security for Genghis and to prevent assassination. The detailed flavor of extensive ${ }^{5}$ specification is conveyed in the following extract:

Further, Cinggis Qa"an issued the following order and proclaimed it to the commanders of the various companies: "When the quiver bearers, the dayguards and the stewards take their turn of duty, they shall carry out their day duties, each at his respective post. As the sun sets, they shall retire so as to be replaced by the nightguards and, going outside, they shall spend the night there. At night, the nightguards shall spend the night beside Us. The quiver bearers shall leave, turning over their quivers - and the stewards their bowls and vessels to the nightguards. ${ }^{6}$

The length and detail of bodyguard prescriptive regulations may have been unique or perhaps typical of other laws. But the fact that it was prominent and presumably verbatim in the History underlines the thesis of Anthrocentric Security Theory - that State, sovereignty, and coercive institutions were erected for life security. The specific bodyguard regulations may have been unique to the Mongols, but were rational as the best means for his protection. He was the "crown" of the Mongol ger, holding the roof in place - the strategic component needed for integrity and completion of the structure. The two pillars (bagana) holding up the roof of the ger could be likened to the bodyguards and the clans.

Transformation of tribal warriors into a unified instrument of the Mongol State was formally accomplished after the Grand Quriltai. Tightening his grip on the army insured central control of military resources, and the Secret History describes it as formation of a bodyguard corps dedicated to protecting the Khan. From the perspective of AST, his command to organize the bodyguard was a set of ancillary SAMs for self-protection at his State Stratum-of- Being. Duties of the guards were detailed, and their primary and supreme responsibility was protection of the Khan. This new elite force consisted of appointed officers who were available for other tasks if needed. A mobile army with movable headquarters could not have stone walls and moats, and so warriors of unquestioning loyalty were appointed to his camp for his protection.

Considering that many of the key incidents were described almost telegraphically in their terseness, expending nearly 3000 words (Rachewiltz 9: 224-234) on detailing the duties of the bodyguards came as close to a legalistic specification as anything found in the Secret History.

6 Rachewiltz 9:229. 


\begin{tabular}{|l|l|}
\hline 1. Stratum-of-Being & State (SB;) \\
\hline 2. Security Action Platform (SAP) & $\begin{array}{l}\text { SAP13: Protective/Coercive } \\
\text { institutions[lls]. }\end{array}$ \\
\hline $\begin{array}{l}\text { 3. Initiator (subject) + predicate + } \\
\text { target (object) }\end{array}$ & $\begin{array}{l}\text { Genghis Khan + organized + } \\
\text { bodyguard }\end{array}$ \\
\hline 4. Intended consequence & Protect the sovereign from harm. \\
\hline 5. Unintended consequence & $\begin{array}{l}\text { Created a new aristocracy based on } \\
\text { merit and clan affiliation }\end{array}$ \\
\hline 6. Resources required v. used & $\begin{array}{l}\text { Men of proven loyalty, merit, } \\
\text { competence. Sons of generals, o } \\
\text { fficers, clan leaders. }\end{array}$ \\
\hline $\begin{array}{l}\text { 7. Actual effect on life-length of } \\
\text { object }\end{array}$ & $\begin{array}{l}\text { Fighting and guarding division of } \\
\text { labor - mutual protection. }\end{array}$ \\
\hline 8. Positive or negative for subject & $\begin{array}{l}\text { Positive for Genghis Khan - } \\
\text { protection from assassination or } \\
\text { other threats. }\end{array}$ \\
\hline 9. Positive or negative for Object & $\begin{array}{l}\text { +Raised status and responsibility of } \\
\text { personal guards. } \\
\text { - made these men hostages to their } \\
\text { kin loyalty }\end{array}$ \\
\hline
\end{tabular}

Figure 10:Genghis Khan organized bodyguard corps

Prior to formal State formation, Genghis employed an informal band of brothers to protect him from assassination and on the battlefield. As Khan, he issued detailed regulations on duties, hours, and deployment of his bodyguard corps. He was concerned over his own safety from possibility of poisoning or sneak attack. It implied that Genghis Khan was not merely an organ of the State (as Minobe framed the Japanese Emperor in the mid-1930s), he was the State personified, and untimely death would dissipate a painfully constructed unity. As Great Khan, Genghis initiated major reorganization of his army, taking the bodyguard as central core of the State and himself as nucleus. Life, as expressed in purposive actions to preserve longevity, was vulnerable to violent ending if not protected. He had secured this "golden life" by vanquishing and exterminating enemies, acquiring allies and warrior disciples, and fathering numerous children with multiple wives and liaisons. His creation of the formal 
bodyguard within his headquarters was a SAM possible only within the State Stratum-of-Being $\left(\mathrm{SB}_{3}\right)$.

This corps also served as a military school for young commanders, using fictive family bond and mutual responsibility to enhance army solidarity. It became a new aristocracy and core of the Mongol State. Bodyguard division of labor provided a prelude to government organization regarding the assignments among guards and chamberlains. The early Mongol State had little in common with bureaucratic States described by Eisenstadt. ${ }^{7}$ Some guards were assigned judicial duties with Sigi Qutuqu. Others cared for weapons and armor, distributing them, or reported on establishing an encampment. The initial Mongol State had more characteristics of an army than a sovereign government.

\section{$\underline{\text { Conclusion }}$}

I have outlined a theory of human life security having universal ramifications, adding detailed illustrations from the Secret History of the Mongols. The approach offers a more scientific approach by means of the existential inversion of normal political discourse - a mode of Platonic monologue or dialogue addressing concepts and political ideas. The existential approach asks a single question:

How does a single human sustain his life? Philosophical anthropology offers some clues and categories, but stops short of exploring the State and civil society as Strata-of-Being, focusing on individual and life-community. The Anthrocentric Security Theory approach is more comprehensive, and requires establishment of an ontological hierarchy consisting of

1. The tangibly real (individual),

2. the consensually real (person), and

3. the legally and conceptually real (Subject).

4. Tentatively, civil society creates the citizen who combines the above three Strata-of-Being, and who remains a derivative Being.

\footnotetext{
"in the Carolingian and Mongol States (or empires), while there did develop rulers with such new types of leadership, there did not exist an appropriate level of differentiation; thus the imperial system could not become institutionalized, and these polities remained at the level of loosely integrated 'conquest' empires, in which the different regions or groups (conquerors and conquered) were not integrated into a polity bound by common symbols of identity, and which basically retained, despite the efforts of their would-be imperial rulers, most of the characteristics of patrimonial systems." S.N.Eisenstadt, The Political System of Empires: The Rise and Fall of Historical Bureaucratic Societies (New York: Free Press, 1969) ix.
} 
These Levels-of-Existence are vacated as follows:

1. Individuality End of Life.

2. Personhood end all physical and mental human contacts, but retain individuality and life.

3. Subjecthood Migrate to territory which no State claims.

Anthrocentric Security Theory postulates that man's primary motivation is to remain alive, and that he has constructed life- communities and States to reinforce his ability to serve longevity.

The life of Genghis Khan compressed a process taking centuries in most other countries. Perhaps due to single-generation State formation and absence of multi-generational consolidation, a stable civilization/civil society was not formed. Nonetheless, the Mongol conquests affected much of Eurasia, destroying old kingdoms and altering trade routes. The Golden Horde was the umbrella under which the Russian State emerged, and assimilated some of its features in later tsardoms. Mongol threats, depredations, occupation and imitators were major factors in evolution of various Asian States as they emerged from medieval semi-feudalism into absolutist modernity. A fuller understanding of traditional and contemporary Asia - as well as Russia - should include consideration of the Mongol impact.

Finally, Anthrocentric Security Theory provides a method and a framework, based on philosophical anthropology, upon which a scientific analysis of the human condition can be undertaken. It postulates a unit for measuring life security - the "human life year," and examines the quantity of these units to discover the inputs and outputs directly affecting that aggregate quantity. The length of every human life is determined by the number, timeliness and quality of its security context. The individual responses to threat and opportunity are a combination of action and knowledge. Biographies of famous persons provide a rich trove of life security data, and subjective, "know thyself" introspection can be even more revealing. Without life security, there can be no life or liberty or pursuit of happiness.

\section{$\underline{\text { Suggested Readings }}$}

Atwood, Christopher Pratt. 2004. Encyclopedia of Mongolia and the Mongol empire.

Avineri, Shlomo. 1968. The Social and Political Thought of Karl Marx. Cambridge: Cambridge University Press.

Banfield, Edward C. 1958. The Moral Basis of a Backward Society. Chicago: Free Press. 
Batbayar, Tsedendamba, and Sharad K. Soni. 2002. Modern Mongolia: A Concise History. New Delhi: Pentagon Press.

Becker, Ernest. 1997. The Denial of Death: New York: Free Press Paperbacks.

Bedeski, Robert E. 2013. "Reinventing Human Security: Lessons from Chinggis Khan's Biography." edited by 2013 .August 19: Stockholm: Institute of Security and Development Policy.

-Sustaining Existence: Lessons from Genghis Khan, A Theory of Life Security, and Roots of

the Asiatic State._https://digital.lib.washington.edu/researchworks/ handle/1773/38457

Benson, Douglas S. 1991. The Mongol Campaigns in Asia. Chicago.

Boyd, Richard, and Tak-Wing Ngo (Eds.). 2006. State Making in Asia. New York: Routledge.

Cassirer, Ernst, and Charles William Hendel. 1946. Myth of the State. New Haven: Yale University Press.

Cua, Antonio S. The unity of knowledge and action: a study in Wang Yangming's moral psychology. (Honolulu: University Press of Hawaii, 1982)

D'Entreves, Alexander Passerin. 1967. The Notion of the State. Oxford: Oxford University Press.

Eisenstadt, S.N. 1969. The Political System of Empires. New York: Free Press. Press.

Fukuyama, Francis. 2004. State-Building. Ithaca, NY: Cornell University

Glubb, John Bagot. 1978. The fate of empires and search for survival. Edinburgh: Blackwood. Greenblatt, Miriam. 2002. Genghis Khan and the Mongol Empire. New York: Benchmark Books. Harari, Y.N. 2015. Sapiens. New York: Harper.

Hartog, Leo De. 1989. Genghis Khan. New York: Barnes \& Noble.

Heidegger, Martin. Nietzsche: v. 1: The Will to Power as Art. (New York: Harper \& Row, 1979)

Hobbes, Thomas. 2004 (1651). Leviathan. edited by 2011 June 02: Gutenberg Project.

Jagchid, Sechin. 1988. Essays in Mongolian studies. Provo, Utah: David M. Kennedy Center for International Studies, Brigham Young University.

Landmann, M. 1974. Philosophical anthropology. Philadelphia: Westminster Press.

Lane, George. 2004. Genghis Khan and Mongol rule. Westport, Conn: Greenwood Press.

Lattimore, Owen. 1962. Inner Asian frontiers of China. Boston: Beacon 
Press.

Livi-Bacci, Massimo. 2007. A Concise History of World Population. Malden, MA: Blackwell.

Maslow, A. H. "A theory of human motivation." Psychological Review. 1943

McLynn, Frank. 2015. Genghis Khan: His Conquests, His Empire, His Legacy. Boston: Da Capo Press.

Paris, Roland. 2001. "Human Security: Paradigm Shift or Hot Air?" International Security 26:2:87-102.

Popper, Karl. The Open Society and Its Enemies, v.1-2: Vol. 1: The Spell of Plato

Vol. 2: The High Tide of Prophecy:Hegel, Marx, and the Aftermath. (Princeton, N.J.: Princeton University Press, 1966)

Rachewiltz, Igor de. 2004. The secret history of the Mongols. Leiden; Boston: Brill.

Ratchnevsky, Paul. 1992. Genghis Khan. Cambridge, USA: Blackwell.

Rossabi, Morris. 1988. Khubilai Khan. Berkeley, CA: University of California Press.

Rubin, Vitaly A. 1976. Individual and State in Ancient China. New York: Columbia University Press.

Sabine, George H. 1961. A History of Political Theory. New York: Holt, Rinehart and Winston.

Sato, Seizaburo. Summer 2000. "Why 'National Defense' Became 'Security."' in Gaiko Forum, 0548 Sato, 'National Defense' Became 'Security' http://www.gaikoforum.com/essay/seizaburosato.htm

Scheler, M. 1962. Man's Place in Nature. Boston: Beacon Press.

Schopenhauer, A. The World as Will and Idea. http://www.gutenberg.org/ files/38427/38427-pdf.

Seiden, Jacob. 1971. The Mongol impact on Russia from the thirteenth century to the present: Mongol contributions to the political institutions of Muscovy, Imperial Russia, and the Soviet State. (v.1).

Shestov, Lev. 1969. Kierkegaard and the Existential Philosophy. Athens, Ohio: Ohio University Press.

Sneath, David (Ed.). 2006. Imperial Statecraft. Bellingham, WA: Western Washington University.

Trubetzkoy, N.S. 1991. Legacy of Genghis Khan and Other Essays on Russia's Identity. Ann Arbor: Michigan Slavic Materials.

Vernadsky, G. 1970. History of Russia. New Haven: Yale University Press.

Weatherford, Jack. 2003. Genghis Khan and the Making of the Modern World. New York: 
Crown.

Weiner, Mark S. 2013. The rule of the clan. New York: Farrar, Straus and Giroux.

Wilson, Woodrow 1890. The State: Elements of Historical and Practical Politics. A Sketch of Institutional History and Administration. Boston: D.C. Heath \& Company.

Wilson., Edward O. 2014. The Meaning of Human Existence. New York: Liveright Publishing Corporation.

Wittfogel, Karl. 1957. Oriental despotism; a comparative study of total power. New Haven: Yale University Press. 